\title{
Estimating Breast Cancer Class Using Artificial Neural Network and Logistic Regression Methods
}

\author{
Serel ÖZMEN-AKYOL *1 \\ ${ }^{1}$ Kütahya Health Sciences University, Faculty of Engineering and Natural Sciences, 43100, Kütahya, \\ https://orcid.org/0000-0002-5344-4065
}

\section{Keywords:}

Artificial Neural Networks,

Fuzzy Neural Networks, Logistic Regression,

Machine Learning

\begin{abstract}
In this study, artificial neural networks (ANN) and logistic regression (LR) prediction models for breast cancer type has been developed. The proposed models are implemented with real clinical data for breast cancer type prediction. For purpose of constructing the prediction model, there are 699 instances and 10 attributes used in training and testing for the model. The data used in the ANN and LR models are arranged in a format of 9 input parameters and an output parameter which is the class of breast cancer (benign or malignant). The evaluation was made by comparing the data obtained by the two methods. ANN and LR models have accuracy performance $94,78 \%$ and $96,18 \%$, respectively. The LR method's accuracy rate is better than the ANN method. This is because the LR method analyzes by taking into account the form of categorical data.
\end{abstract}

\section{Yapay Sinir Ăğ ve Lojistik Regresyon Yöntemleri Kullanılarak Meme Kanseri Sınıfının Tahmin Edilmesi}

\section{Anahtar Kelimeler: \\ Yapay Sinir Ağları, Bulanık Sinir Ağları, Lojistik Regresyon, Makine öğrenmesi}

\begin{abstract}
Özet: $\mathrm{Bu}$ çalışmada meme kanseri tipi için Yapay Sinir Ağları (YSA) ve Lojistik Regresyon (LR) tahmin modelleri geliștirilmiștir. Önerilen modellere, meme kanseri tipi tahmini için gerçek klinik veriler uygulanmaktadır. Tahmin modeli oluşturmak amacıyla, modelin eğitiminde ve test edilmesinde kullanılan 699 örnek ve 10 öznitelik bulunmaktadır. YSA ve LR modellerinde kullanılan veriler, 9 giriş parametresi ve meme kanseri sınıfı (iyi veya kötü huylu) olan bir çıkış parametresi şeklinde düzenlenmiştir. Değerlendirme, iki yöntemle elde edilen veriler karşılaştııılarak yapılmıștır. ANN ve LR modelleri sırasıyla $94,78 \%$ ve $96,18 \%$ doğruluk performansına sahiptir. LR yönteminin doğruluk oranı, ANN yönteminden daha iyidir. Bunun nedeni, LR yönteminin analizleri kategorik verilerin yapısını dikkate alarak yapmasıdır.
\end{abstract}

\section{INTRODUCTION}

Automatic disease diagnosis systems are important for medical fields. Prediction models help healthcare professionals and patients make clinical decisions. Type prediction for different diseases is crucial in medical decision-making, especially when numerous factors affect the appearance of that disease or disorder. This is quite a complex process. Therefore, cancer prediction systems which consider various variables for the prediction of an outcome require computational intelligent methods for efficient prediction outcomes [1].
Breast cancer is a very common class of cancers among women. Breast cancer is one such disease with various aspects, which inflicts huge expenses on the individual and the society and is identified in the United States as the most common cancer type among women, and second most frequent cause of cancer mortality [2]. Breast cancer diagnosis (BCD) is done either during a screening examination, before or after symptoms have developed, or when a woman feels a lump. Most masses seen on mammogram and most breast lumps turn out to be benign, which means that the lump is not life- threatening. Generally, when a breast cancer is detected based on clinical exam or breast imaging, microscopic analysis of breast lump is necessary for a definitive diagnosis of the patient status. Therefore, the economic and social values 
of BCD systems are very high. This area of research has long attracted the attention of the Bioinformatics and Artificial Intelligence communities [2].

Artificial learning and machine learning are the areas of research based on the learning and estimation of computers using sample data and past experience as people. In the recent decades, new methods such as artificial neural networks (ANNs) and logistic regression (LR) of these methods have been used to develop the predictive models to estimate the needed parameters.

AI-based classifiers such as ANN are used the last phase of Computer-Aided Diagnosis (CAD) system [3]. In the literature, these applications are included in many disease and cancer studies in estimating cancer staging [4], and type [5], classification [6], [7], risk assessment [8] and diagnosis of disease [9], [10], decision making [11] and improving the accuracy of cancer survival prediction [12].

The logistic regression analysis, is one of the most common machine learning method used for classification and prediction of disease data [13], [14]. Logistic regression analysis, which is one of the means for multivariate analysis, is preferred because of permitted recognition of independent variables associated with disease, which dependent variable and their significance tests [15]. Therefore, there are many studies in which logit-based methods have been successfully applied in disease and cancer classification and evaluation [16]. Shipe et al. were described a set of guidelines and heuristics for clinicians to use to develop a logistic regression-based prediction model for binary outcomes that is intended to augment clinical decision-making [17]. Coşkun et al. were studied on dentistry data to determine important risk factors of take prosthesis for describing the application of logistic regression analysis [18].

Breast cancer is a very common disease. The type of cancerous cell in the treatment and diagnosis is very important. This study presents the use of artificial neural networks (ANN) and logistic regression (LR) analysis for prediction breast cancer type. Due to the discrete form of the cancer type, which is the dependent variable, LR method was preferred. The aim of this study is to build prediction models using artificial neural networks (ANN) and logistic regression (LR) methods to predict breast cancer type and compare the two different models' performances.

\section{MATERIALS AND METHODS}

\subsection{Artificial Neural Network}

Artificial neural networks (ANN) are a form of computing for predicting a set of outputs from a set of input variables. This method is based on the functioning of biological neural networks that consist of links and neurons. The neurons are processing units. And the links provide connections between neurons. A commonly used form of ANN consists of layers as one input layer, zero, one or two hidden layer(s), and one output layer. The links connect the neurons from input to hidden or hidden to output layers. Most ANNs just have one hidden layer. The neurons in the input layer receive input patterns and send those inputs through the links to the neurons on the hidden layer, which then process the inputs and send the results to neurons in the output layer for processing and presentation. The application of ANN consists of two general steps: network training and network application. Network training uses samples, each of which contains an input pattern and the expected output pattern for that sample, to develop associations between a set of input patterns and a set of output patterns. The network application step uses the trained network to predict an output pattern for a given input pattern whose corresponding output pattern is unknown [12]. Artificial neural networks and fuzzy artificial neural network methods are used in the literature to predict the situation and to classify these situations in many studies. Artificial neural networks are basically based on the working principle of the human brain. Artificial neural networks are used with the computer software which is created by giving the machine-specific features to the machine. Artificial neural networks have been developed using the working principle of the human brain. In this structure, which is based on the communication of neurons with each other, there are various weights among the nodes. These are parallel distributed processing structures, which are interconnected by means of these connections, each of which is made up of processing elements which have separate memories. The main goal of artificial neural networks is to imitate the structure of biological neural networks in the human brain with computer programs.

The structure of artificial neural networks usually comes from three layers;

- the input layer,

- hidden layer

- output layer

A network structure with two hidden layers is in Figure 1. The input of a neuron is the output of another neuron. cell in the structure. The outputs are transmitted through the connections as shown. Connections are expressed by numerical values, called weight, located between neurons [19].

All nodes after the input layer sum the inputs to them and use a transfer function (also known as an activation function) to send the information to the adjacent layer nodes. The transfer function is usually a sigmoid function. 


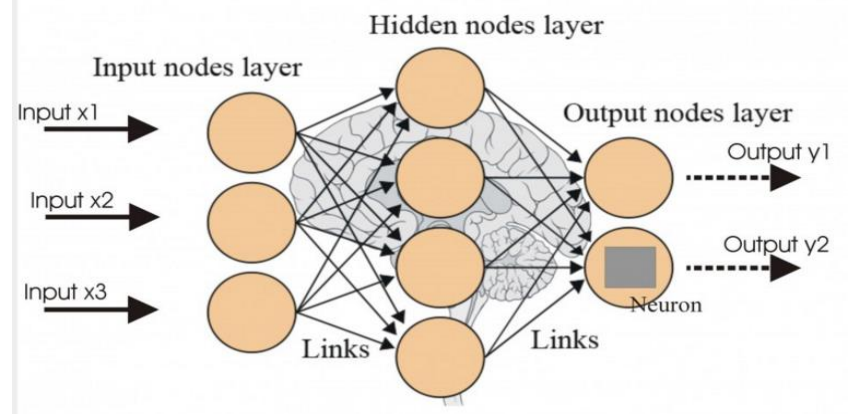

Figure 1. Structure of the artificial neural networks (ANNs) models

The sigmoid function is represented by Eq. (1) and gives outputs between 0 and 1 . When it is desired, the outputs of this function can be adjusted to between -1 and 1 . The connections between the nodes have adjustable weights that specify the extent to which the output of one node will be reflected in the activity of the adjacent layer nodes. These weights, along with the connections among the nodes, determine the output of the network [12].

$$
o_{j}=f(\text { net })_{j}=\frac{1}{1+e^{-\alpha(n e t)_{j}}}
$$

The learning algorithm, which is often used in many areas with engineering sciences, is a back-propagation algorithm. In this study, the back-propagation algorithm will be used as the learning algorithm. The most important reason why this algorithm is preferred is that the learning performance is very high and the learning algorithm is simple.

The main purpose of the back propagation algorithm is; (Gradient descent algorithm) reduce the square error to the minimum. The quadratic error used in this expression is; difference between the "y" value, which is the actual output of the system, and the "d" value, which is the desired output from the system [20].

\subsection{Logistic Regression}

Logistic regression analysis, which is used to examine the relationship between dependent and independent variables and to classify, is one of the preferred machine learning methods because it allows the dependent variable to take categorical values [21], [22]. There is no restriction such as whether the independent variables form used in the analysis are continuous or discrete/categoric [23]. Advantages of logistic regression are that it allows the evaluation of multiple explanatory variables by extension of the basic principles and the use of dependent variable in discrete form [24].

It is aimed to establish an acceptable model that can describe the relationship between the outcome variable (dependent or response variable) and the set of independent variables (explanatory variables) in a way that has the best fit using logistic regression analysis [18], [25].

By using logistic regression analysis, the probability of the event to occur is expressed according to the state of the independent variables in the analysis. The general logistic regression equation is [26]:

$$
P=\frac{e^{a+b * X}}{1+e^{a+b * X}}=\frac{1}{1+e^{-(a+b * X)}}
$$

The probability of the observed case in the multiple logistic regression analysis is expressed in the Eq.3 [26].

$$
\begin{aligned}
P & =\frac{e^{\beta_{0}+\beta_{1} X_{1}+\cdots+\beta_{k} X_{k}}}{1+e^{\beta_{0}+\beta_{1} X_{1}+\cdots+\beta_{k} X_{k}}} \\
& =\frac{1}{1+e^{-\left(\beta_{0}+\beta_{1} X_{1}+\cdots+\beta_{k} X_{k}\right)}}
\end{aligned}
$$

In the equation, $P$ value indicates the probability of observing the evaluated event, and $\beta$ values indicate the logistic regression coefficients of the independent variables. The value of $\beta_{0}$ is the constant value of the model, expressing the value of the dependent variable if all the independent variables in the model are equal to zero. $X$ values represent the independent variables, and $k$ indicates the count of independent variables [21], [26].

\subsection{Data and Preprocessing}

In this study, Artificial Neural Network (ANN) and Logistic Regression (LR) methods were used to predict the type of breast cancer. The data used in the training of ANN and LR models were taken from measurements was obtained from the University of Wisconsin Hospitals, Madison by Dr. William H. Wolberg [27]. 699 instances and 10 plus the class attributes from the sample breast cancer database were used in training and testing for the models. Attribute information was used is in Table 1.

The data used in the ANN and LR models are arranged in a format of 9 input parameters (Clump Thickness, Uniformity of Cell Size, Uniformity of Cell Shape, Marginal Adhesion, Single Epithelial Cell Size, Bare Nuclei, Bland Chromatin, Normal Nucleoli and Mitoses) and an output parameter which is the class of breast cancer (benign or malignant). Evaluation will be made by comparing the data obtained by the two methods.

The sample data set consists of $458(65.5 \%)$ benign class and $241(34.5 \%)$ malignant class instances and is randomly divided into 450 and 249 of the instances for the training and the testing of ANN and LR models, respectively. Models were trained on the same training data set and tested with the same test data set. 
Table 1. Attribute Information

\begin{tabular}{|c|c|c|}
\hline Number & Attribute & Domain \\
\hline 1 & Sample code number & id number \\
\hline 2 & Clump Thickness & $1-10$ \\
\hline 3 & Uniformity of Cell Size & $1-10$ \\
\hline 4 & Uniformity of Cell Shape & $1-10$ \\
\hline 5 & Marginal Adhesion & $1-10$ \\
\hline 6 & Single Epithelial Cell Size & $1-10$ \\
\hline 7 & Bare Nuclei & $1-10$ \\
\hline 8 & Bland Chromatin & $1-10$ \\
\hline 9 & Normal Nucleoli & $1-10$ \\
\hline 10 & Mitoses & $1-10$ \\
\hline \multirow{2}{*}{11} & Class: & $\begin{array}{l}\text { (2 for benign, } \\
\text { 4 for malignant })\end{array}$ \\
\hline
\end{tabular}

Normalization operation is applied for making the values conform to or reduce to a norm or standard. There are different normalization processes [28]. Normalization is usually made column-wise and the normalized value range is expected to be 0 to 1 [29]. The input and output variables are normalized between 0.1 and 0.9 by using Eq. 4.

$$
x^{\prime \prime}=\left(\frac{x-x_{\min }}{x_{\max }-x_{\min }}\right) 0.8+0.1
$$

Where $x^{\prime \prime}$ is normalized value, $x$ is value to be normalized, $x_{\min }$ and $x_{\max }$ values minimum and maximum value in the data set, respectively [30].

\section{RESULTS}

ANN and LR analysis were implemented on MATLAB (MATLAB is a registered trademark of The MathWorks, Inc.). The ANN model consists of feed-forward back propagation, one hidden layer with eight neurons, training function (Levenberg-Marquardt), adaptation learning function (learngdm), transfer function (tansig) and performance function (MSE-mean squared error) as demonstrated in Fig. 2.



Figure 2. The architecture used in the neural network model for prediction breast cancer type

This ANN model is called as a multi-layer perceptron (MLPNN). The neurons are 8 and 1 at the first and the second layers in the system, respectively. Momentum and learning rate values were determined and the MLPNN model was trained according to the MSE through iterations. The parameter values obtained from the MLPNN model were given in Table 2.
Table 2. The values of parameters used in models

\begin{tabular}{|l|c|}
\hline \multicolumn{1}{|c|}{ Parameters } & MLPNN \\
\hline Number of input layer neurons & 9 \\
\hline Number of hidden layer & 1 \\
\hline Number of hidden layer neurons & 8 \\
\hline Number of output layer neuron & 1 \\
\hline
\end{tabular}

The trained model was tested only with the input values and the predicted results were close to the experimental results. ANN Model accuracy is $94,77911647 \%$.

The logistic regression model, which is the second method proposed in the study was created with 8 independent and 1 dependent variables. All independent variables were included in the logistic regression model by using the enter method with same training dataset. Cancer type, which is the dependent variable was estimated by using LR coefficients obtained according to this model. The LR coefficients obtained as a result of the training of the LR model were given in Table 3.

Table 3. LR Coefficients

\begin{tabular}{|c|c|c|c|c|}
\hline Number & Attribute & $\beta$ & Wald & Sig. \\
\hline$\beta_{0}$ & Constant & $-6,974$ & 50,258 & 0,000 \\
\hline$\beta_{1}$ & $\begin{array}{l}\text { Clump } \\
\text { Thickness }\end{array}$ & 3,852 & 7,706 & 0,006 \\
\hline$\beta_{2}$ & $\begin{array}{l}\text { Uniformity } \\
\text { of Cell Size }\end{array}$ & 3,703 & 1,835 & 0,176 \\
\hline$\beta_{3}$ & $\begin{array}{c}\text { Uniformity } \\
\text { of Cell } \\
\text { Shape }\end{array}$ & 2,355 & 1,018 & 0,313 \\
\hline$\beta_{4}$ & $\begin{array}{l}\text { Marginal } \\
\text { Adhesion }\end{array}$ & 1,111 & 0,606 & 0,436 \\
\hline$\beta_{5}$ & $\begin{array}{c}\text { Single } \\
\text { Epithelial } \\
\text { Cell Size } \\
\end{array}$ & 2,531 & 1,440 & 0,230 \\
\hline$\beta_{6}$ & Bare Nuclei & 4,380 & 18,432 & 0,000 \\
\hline$\beta_{7}$ & $\begin{array}{c}\text { Bland } \\
\text { Chromatin }\end{array}$ & 2,130 & 1,231 & 0,267 \\
\hline$\beta_{8}$ & $\begin{array}{c}\text { Normal } \\
\text { Nucleoli }\end{array}$ & $-1,304$ & 0,724 & 0,395 \\
\hline$\beta_{9}$ & Mitoses & 5,416 & 3,998 & 0,046 \\
\hline
\end{tabular}

The equation to be used for breast cancer type classification is as follows:

$$
\begin{aligned}
\hat{y}= & -6,974+3,852 x_{1}+3,703 x_{2}+2,355 x_{3} \\
& +1,111 x_{4}+2,531 x_{5}+4,380 x_{6}+2,130 x_{7} \\
& -1,304 x_{8}+5,416 x_{9}
\end{aligned}
$$

LR model fit values for prediction class of Breast Cancer, were presented in Table 4 . The decrease in the -2 Log Likelihood value in the tried model indicates model fit. Cox \& Snell and Nagelkerke $\mathrm{R}^{2}$ values of 1 indicate that the model shows a perfect fit. 
Table 4. Goodness of fit values for the Model

\begin{tabular}{|c|c|c|}
\hline -2 Log likelihood & Cox \& Snell $\mathbf{R}^{2}$ & Nagelkerke $\mathbf{R}^{2}$ \\
\hline 67,228 & 0,676 & 0,938 \\
\hline
\end{tabular}

The reliability of the obtained Logistic regression model was tested with the Hosmer Lemeshow test,

$\mathrm{H}_{0}$ : Estimation equation is significant,

$\mathrm{H}_{1}$ : Estimation equation is not significant,

As a result of the Hosmer Lemeshow test, the Chi-Square value was calculated as 0,63 . It was obtained as $\mathrm{p}=1,000$ $>\alpha=0,05$ and $\mathrm{H}_{0}$ hypothesis that the model was suitable was accepted.

Model prediction values were obtained by applying coefficients to the test data set. Accordingly, the logistic regression model accuracy rate of Equation 5 obtained according to the results in Table 3 is 96,18072289\%, which is quite a high rate. Therefore, this value is an indication that the equation is significant.

\section{DISCUSSION AND CONCLUSION}

Artificial Neural Networks are preferred for many complex problems solving and are also ideally suited to help people solve complex problems in real-life situations such as medical. ANN model can learn and define the relationships between inputs and outputs that are nonlinear and complex; make generalizations and inferences; to create patterns and predictions. In this way, ANN can improve decision processes in different areas.

The Logistic Regression method is used to understand the relationship between the dependent variable and one or more independent variables by estimating probabilities using a logistic regression equation. In this way, predictable the likelihood of an event happening or a choice being made.

In this study, ANN and LR methods were used to Prediction Breast Cancer Type according to the Clump Thickness, Uniformity of Cell Size, Uniformity of Cell Shape, Marginal Adhesion, Single Epithelial Cell Size, Bare Nuclei, Bland Chromatin, Normal Nucleoli and Mitoses independent attributes.

The proposed ANN and LR methods were trained and tested on breast cancer data. The experimental results show that the LR method can be more consistent with the existing dataset knowledge and with high accuracy. This is because the LR method analyzes by taking into account the form of categorical data.

The Breast Cancer Wisconsin Data Set [27] in which the analyzes were made in this study is a data set with high accuracy that is frequently used in machine learning methods. Unlike other studies, classification was made with the LR method and the results of the ANN method analysis were compared. In future studies, the two methods used in this study should be evaluated by applying them to different data sets.

\section{REFERENCES}

[1] G. Cosma, G. Acampora, D. Brown, R. C. Rees, M. Khan, and A. G. Pockley, "Prediction of Pathological Stage in Patients with Prostate Cancer: A NeuroFuzzy Model," PLoS One, vol. 11, no. 6, pp. 1-27, 2016.

[2] A. Atashi, N. Nazeri, E. Abbasi, S. Dorri, and M. Alijani-Z, "Breast Cancer Risk Assessment Using Adaptive Neuro-Fuzzy Inference System (ANFIS) and Subtractive Clustering Algorithm," Multidiscip. Cancer Investig., vol. 1, no. 2, pp. 20-26, 2017.

[3] B. S. Khehra and A. P. S. Pharwaha, "Classification of clustered microcalcifications using MLFFBP-ANN and SVM," Egypt. Informatics J., vol. 17, no. 1, pp. 11-20, 2016.

[4] G. Cosma, G. Acampora, D. Brown, R. C. Rees, M. Khan, and A. G. Pockley, "Prediction of Pathological Stage in Patients with Prostate Cancer: A NeuroFuzzy Model," PLoS One, vol. 11, no. 6, pp. 1-27, 2016.

[5] A. Rezaei, L. Noori, and M. Taghipour, "The Use of ANFIS and RBF to Model and Predict the Inhibitory Concentration Values Determined by MTT Assay on Cancer Cell Lines," Int. J. Inf. Technol. Comput. Sci., vol. 8, no. 4, pp. 28-34, 2016

[6] G. Mohan and M. M. Subashini, "MRI Based Medical Image Analysis: Survey on Brain Tumor Grade Classification," Biomed. Signal Process. Control, vol. 39, pp. 139-161, 2018.

[7] B. D. Barkana, I. Saricicek, and B. Yildirim, "Performance Analysis of Descriptive Statistical Features in Retinal Vessel Segmentation via Fuzzy Logic , ANN , SVM , and Classifier Fusion," Knowledge-Based Syst., vol. 118, pp. 165-176, 2017.

[8] H. Korkmaz, E. Canayaz, S. Birtane, and Z. A. Altikardes, "Fuzzy Logic Based Risk Assessment System Giving Individualized Advice for Metabolic Syndrome and Fatal Cardiovascular Diseases," Technol. Heal. Care, vol. 27, no. S1, pp. S59-S66, 2019.

[9] H. Olmuş and S. Erbaş, "Bayes Ağlarda Kümeleme Metotunu Kullanarak Meme Kanseri Tanısının Modellenmesi," Turkiye Klin. J Biostat, vol. 4, no. 1, pp. 10-19, 2012

[10] S. Bilgiç, M. S. Öğün, K. Akgün, and D. Özdemir, "Sağlık Sektöründe Blockchain (Blok Zincir) Uygulamalar1," in 1st International Hazar Scientific Research Conference Baku, 2020, pp. 938 949.

[11] E. I. Papageorgiou, N. I. Papandrianos, D. Apostolopoulos, and P. Vassilakos, "Complementary Use of Fuzzy Decision Trees and Augmented Fuzzy Cognitive Maps for Decision Making in Medical Informatics," in 2008 International Conference on BioMedical Engineering and Informatics, 2008, vol. 1, pp. 888-892.

[12] H. B. Burke et al., "Artificial Neural Networks 
Improve the Accuracy of Cancer Survival Prediction," Am. Cancer Soc., vol. 79, no. 4, pp. 857-862, 1997.

[13] X. Zhou, K. Y. Liu, and S. T. C. Wong, "Cancer Classification and Prediction Using Logistic Regression with Bayesian Gene Selection," J. Biomed. Inform., vol. 37, no. 4, pp. 249-259, 2004.

[14] Y. Atakurt, "Lojistik Regresyon Analizi ve Tip Alanında Kullanımına İlişkin Bir Uygulama," Ankara Üniversitesi Tıp Fakültesi Mecmuası, vol. 52, no. 4, pp. 191-199, 1999.

[15] Y. Kitiş, N. Bilgili, F. Hisar, and S. Ayaz, "Yirmi Yaş ve Üzeri Kadınlarda Metabolik Sendrom Sıklığı ve Bunu Etkileyen Faktörler," Anatol. J. Cardiol., vol. 10, pp. 111-119, 2010.

[16] Y. Yengi and S. İlhan Omurca, "Lojistik Regresyonun Özellik Azaltma Teknikleri ile Gen Dizilimlerinin Sınıflandırılmasındaki Başarısı," Türkiye Bilişim Vakfı Bilgi. Bilim. ve Mühendisliği Derg., vol. 8, no. 1, pp. 1-12, 2015.

[17] M. E. Shipe, S. A. Deppen, F. Farjah, and E. L. Grogan, "Developing Prediction Models for Clinical Use Using Logistic Regression: An Overview," J. Thorac. Dis., vol. 11, no. Suppl 4, pp. S574-S584, 2019.

[18] S. Coşkun, M. Kartal, A. Coşkun, and H. Bircan, "Lojistik Regresyon Analizinin İncelenmesi ve Dişhekimliğinde Bir Uygulaması," Cumhur. Üniversitesi Diş Hekim. Fakültesi Derg., vol. 7, no. 1, 2004.

[19] İ. Kaya, S. Oktay, and O. Engin, "Kalite Kontrol Problemlerinin Çözümünde Yapay Sinir Ağlarının Kullanımı," Erciyes Üniversitesi Fen Bilim. Enstitüsü Derg., vol. 21, no. 1-2, pp. 92-107, 2005.

[20] M. Caner and E. Akarslan, "Mermer Kesme İşleminde Spesifik Enerji Faktörünün ANFIS ve YSA Yöntemleri ile Tahmini Estimation of Specific Energy Factor in Marble Cutting Process Using," Pamukkale Üniversitesi Mühendislik Bilim. Derg., vol. 15, no. 2, pp. 221-226, 2009.
[21] F. E. Harrell, "Binary Logistic Regression," in Regression Modeling Strategies, 2nd ed., Cham,Switzerland: Springer Series in Statistics,Springer, 2015, pp. 219-274.

[22] D. Lei, M. Du, H. Chen, Z. Li, and Y. Wu, "Distributed Parallel Sparse Multinomial Logistic Regression," IEEE Access, vol. 4, pp. 1-13, 2016.

[23] A. Agresti, An Introduction to Categorical Data Analysis, 2nd ed. Florida, United States: Wiley, 2007.

[24] J. I. E. Hoffman, "Logistic Regression," in Biostatistics for Medical and Biomedical Practitioners, Tiburon, California, USA: Elsevier, 2015, pp. 601-611.

[25] Ö. Çokluk, G. Şekercioğlu, and Ş. Büyüköztürk, Sosyal Bilimler için Çok Değişkenli İstatistik SPSS ve LISREL Uygulamalar [SPSS and LISREL Applications of Multivariate Statistics for the Social Sciences], 2. Ankara, Turkey: Pegem Akademi, 2012.

[26] D. W. Hosmer and S. Lemeshow, Applied Logistic Regression, 2nd ed. Hoboken, NJ,USA: John Wiley \& Sons, Inc., 2000.

[27] "Breast Cancer Wisconsin (Original) Data Set." [Online]. Available: https://archive.ics.uci.edu/ml/datasets/breast+cancer+ wisconsin+(original).

[28] U. KUT and E. GÜLBANDILAR, "Yapay Zekâ Uygulamasıyla Seramik Nesnelerin Şekilsel Deformasyonun İncelenmesi : ANFIS," ESTUDAM Bilişim Derg., vol. 1, no. 1, pp. 12-16, 2020.

[29] H. S. Shih, H. J. Shyur, and E. S. Lee, “An extension of TOPSIS for group decision making," Math. Comput. Model., vol. 45, no. 7-8, pp. 801-813, 2007.

[30] İ. Gölcük and A. Baykasoğlu, "An Analysis of DEMATEL Approaches for Criteria Interaction Handling within ANP," Expert Syst. Appl., vol. 46, pp. 346-366, 2016. 